\title{
ENFORCING DISCOVERY OF DOCUMENTS UNDER FEDERAL RULE 34: THE EFFECT OF FOREIGN LAW ON THE CONCEPT OF CONTROL*
}

Federal Rule of Civil Procedure 34 authorizes a court, at the request of a litigant showing good cause, to order pre-trial discovery of relevant doctments in the "possession, custody, or control" of an opposing party. ${ }^{1}$ If the discovery order is disobeyed Rule 37(b) allows the court to impose "just" sanctions against the disobedient party including striking of his pleadings, dismissal, or entry of default judgment. ${ }^{2}$ When the party from whom the papers are sought (the deponent) has no control over them, no discovery order can issue, and the party seeking discovery (the proponent) must proceed to trial without inspecting the documents. ${ }^{3}$ Whether a party controls

*Société Internationale Pour Participations Industrielles et Commerciales, S.A. v. McGranery, 111 F. Supp. 435 (D.D.C. 1953).

1. FED. R. Civ. P. 34 provides:

"Upon motion of any party showing good cause therefore and upon notice to all other parties ... the court in which an action is pending may (1) order any party to produce and permit the inspection and copying or photographing, by or on behalf of the moving party, of any designated documents, papers, ... or tangible things, not privileged, which constitute or contain evidence... and which are in his possession, custody, or control. ...."

Rule 34 requires a court order before discovery may be made. The order does not issue automatically upon proponent's motion; granting discovery involves an exercise of the court's discretion. Hudalla v. Chicago, M., St. P. \& P.R.R., 10 F.R.D. 363 (D. Minn. 1950).

For a general treatment of Rule 34, see 4 Moore, Federal Practice $\{34.01$ (2d cd. 1950).

2. FED. R. CIV. P. 37(b) (2) provides:

"If any party ... refuses to obey an order made under . . . Rule 34 . . the court may make such orders in regard to the refusal as are just, and among others the following:

"(i) an order that the matters [which] ... the contents of the paper [allegedly prove] ... shall be taken to be established for the purposes of the action in accordance with the claim of the party obtaining the order;

"(ii) an order ... prohibiting [the disobedient party] from introducing in cvidence designated documents...

"(iii) an order striking out pleadings or parts thereof, or staying further procecdings until the order is obeyed, or dismissing the action or proceeding or any part thercof, or rendering a judgment by default against the disobedient party. .."

3. Although Rule 34 only requires that the deponent have possession, custody, or control, courts have held that control is the real test, since emphasis merely on possession or custody could contravene the spirit of the Rule. Bifferato v. States Marine Corp. of Delaware, 11 F.R.D. 44 (S.D.N.Y. 1951) ; In re Harris, 27 F. Supp. 480 (S.D.N.Y. 1939) (designated bank records were physically in the deponent's possession; but the court, interpreting the National Banking Act, found that he had no legal control over the records and withdrew its discovery order). 
designated documents is a question of fact. ${ }^{4}$ Courts have never found control when the documents sought were lost, ${ }^{5}$ destroyed, ${ }^{0}$ or otherwise unavailable to the deponent. ${ }^{7}$

In Société Internationale Pour Participations Industrielles ct Commerciales, S.A. v. McGranery, ${ }^{8}$ a court considered for the first time whether the operation of foreign law should be a factor in determining if a party has control over documents. Plaintiff, a Swiss corporation, sued to recover property seized by the United States under the Trading with the Enemy Act. ${ }^{\circ}$ On the Government's motion, the court ordered plaintiff to produce its corporate records, which were located in Switzerland.10 Swiss penal law, however, forbade disclosure of such information. ${ }^{11}$ And to prevent compliance with the

4. Courts have consistently held that proponent's right to a discovery order is conditioned upon his showing, inter alia, that deponent has control over the requested documents. Meier Glass Co. v. Anchor Hocking Glass Corp., 11 F.R.D. 487 (W.D. Pa. 1951); Hirshhorn v. Mine Safety Appliances Co., S F.R.D. 11 (W.D. Pa. 1948).

5. Campbell v. Johnson, 101 F. Supp. 705 (S.D.N.Y. 1951).

6. Roth v. Paramount Pictures Distributing Corp., S F.R.D. 31 (W.D. Pa. 1948).

7. Reeves v. Pennsylvania R.R., S0 F. Supp. 107, 109 (D. Del. 1948) (deponent had no legal power to compel her doctor to give her $\mathrm{X}$-rays which proponent sought) ; Valenstein v. Bayonne Bolt Corp., 6 F.R.D. 363, 366 (E.D.N.Y. 1946) (deponent had sold the items designated in the discovery order before he brought suit); Blumenthal v. Lulaes, 2 F.R.D. 427 (S.D.N.Y. 1942) (the designated corporate records, if extant, were in Hungary, and not in deponent's control).

8. 111 F. Supp. 435 (D.D.C. 1953) (hereinafter cited as Société Internationale v. MicGranery), 66 Harv. L. Rev. 1316. Subsequent to this decision Attorney-General Brownell, Mr. MrGranery's successor, has been substituted as defendant in the case.

9. 40 Stat. 411 (1917), as amended, 55 Star. $\$ 39$ (1941), 50 U.S.C.Apr. $\$ 1$ (1946). Section 9(a) of the Act provides that any person-except an enemy or an enemy allywith an interest in money or property vested in the United States Government under authority of the Act may file a claim to recover his property. For a detailed study of the provisions relating to the return of seized property, see Comment, 62 YALE L.J. 1210 (1953),

10. The United States claimed the records would show that corporate control of the plaintiff rested in enemy hands; plaintiff argued that the records would prove its neutral gwnership and were therefore of more importance to it than to the defendant. Societte Internationale v. McGranery, 111 F. Supp. 435, 442 (D.D.C. 1953).

11. In complying with the discovery order, the deponent would have violated three Swiss penal statutes.

The Economic Espionage Act makes it a crime to reveal a "business secret" to a "foreign official" or his agent. Swiss Penal Cone Art. 273 (1942). Defendant elaimed that plaintiff could induce its depositors to waive this provision. But the court-3ppointed Miaster concluded that waivers would be ineffectual, since government as well as private business secrets were involved. Spectal MAASter's Report, Opinion pp. 121-5; Findisgs of Fact Nos. 26-\$, 107-137 (July 9, 1952), Sociéte Internationale v. McGranery, 111 F. Supp. 435 (D.D.C. 1953).

The Banking Act imposes penalties on a bank officer or employee who wilfully divulges bank secrets. Swrss Banking ACT Art. 47 (1934). Although depositors can also waive this statute, the Master found that the thousands of records involved in this case made it practically impossible for plaintiff to procure waivers. Specral Master's Rerozr, op. cil. supra, Opinion pp. 130-1; Findings of Fact Nos. 13S-42; Conclissions Nos. 9, 10. 
discovery order, Swiss authorities seized the documents. ${ }^{12}$ The court accepted a Master's finding that plaintiff was in no way responsible for the taking and had made bona fide efforts to produce the records. ${ }^{13}$ Nevertheless, choosing to ignore Swiss seizure, the court found that plaintiff had control over its records. ${ }^{14}$ Hence, it dismissed the complaint with prejudice because plaintiff, despite its good faith, had failed to comply with the discovery order.15

Finally, a general section of the penal statutes forbids any unathorized person to undertake on Swiss territory any action in behalf of an official of a foreign government -or to abet such action. Swiss PENAl Code Art. 271 (1942). To avoid violating this Article, plaintiff would have had to receive the Swiss government's permission to comply with the discovery order. No permission was granted. SPECtar. Master's RepoRT, op. cit. stipra, Opinion pp. 18-20; Findings of Fact Nos. 11-18.

12. For the full text of the seizure order, see SPECtal Master's Report, op. cit. supra note 11, Opinion pp. 2-3. The court described the seizure as "constructive possession by interdiction" and not a "physical taking," Société Internationale v. McGrancry, 111 F. Supp. 435, 439 (1952), and the Special Master found that production or an attempt to produce was theoretically not impossible although it would constitute an additional crime under Swiss law. SPEctal MASTER's Report, op. cit. supra note 11, Findings of Fact No. 5. However, the Swiss Federal Attorney's seizure order entrusts the Federal police with its execution, and neither defendant nor the court contended that plaintiff actually could have produced the records covered by the order. Indeed the court, in announcing the grounds for its decision, stated: "The principle is the same, whether the information is locked in the breast of a party by a foreign government's order or whether it is locked in its chests or vaults by the same government order." Société Internationale v. McGranery, supra, at 444 . This Note will proceed on the assumption that for all practical purposes the Swiss government had in fact seized the documents.

The preventive police power, which made seizure possible, stems from Art. $102, \S 10$ of the Swiss Constitution and from customary Swiss law. It gives the Federal Attorney the right to forestall imminent violations of any section of the Penal Code or the Bankingt Law. Spectal Master's Report, op. cit. supra note 11, Findings of Fact Nos. 77-97.

13. The Special Master held hearings on eighteen separate occasions, considered numerous exhibits, and took testimony from plaintiff's officers and from experts on Swiss law. Spectal Master's Report, op. cit. supra note 11, Opinion p. 5. He concluded that plaintiff had demonstrated its good faith by making the efforts a "reasonable man would make who desired to achieve effective compliance with [the] Court's order." Id., Contchisions Nos. 2, 7; Findings of Fact Nos. 25-43. He also determined that under Swiss law the seizure order was justified, and that the Swiss government had not altered the customary operation or enforcement of its laws to aid the plaintiff. Id. Nos. 4, 5.

14. Société Internationale v. McGranery, 111 F. Supp. 435, 438, 442 (D.D.C. 1953). The court had found that plaintiff had control of the records when it first issued the discovery order. Société Internationale Pour Participations Industrielles et Commerciales, S.A. v. Clark, 9 F.R.D. 263 (D.D.C. 1949).

15. The dismissal was to take effect on June 15, 1953, unless plaintiff produced the documents in the interim. See order entered by the court, March 31, 1953, stubsequent to Société Internationale v. McGranery, supra note 14. But because plaintiff was appealing the seizure order to the Swiss Federal Council, the court postponed the effective date of dismissal until July 15, 1953. N.Y. Times, June 16, 1953, p. 39, col. 5.

The court in Sociéte Internationale framed the issue presented for decision in terms of a non-complying plaintiff, Société Internationale v. McGranery, supra at 443. But portions of the opinion seem to apply with equal force to defendant-deponents. Sce notes 26, 27 infra. 
In Société Internationale, the documents sought had not been seized when the court first ordered the plaintiff to produce them. ${ }^{10}$ The court might then have found control on the ground that plaintiff did physically possess the records, even though revealing their contents would have violated Swiss law. ${ }^{17}$ But ordering discovery in such a situation would force many litigants into the hapless choice between forfeiting their lawsuit in this country by disobeying the order and incurring substantial criminal or civil liability abroad for performing an unlawful act. ${ }^{18}$ Courts have never directed a party to commit an unlawful act. ${ }^{10}$ Consequently, they should not issue a discovery

16. The court issued its discovery order on July 5, 1949 and ordered the designated documents produced on June 29,1950. The Swiss Government issued its seizure order two weeks prior to the 1950 deadline. Société Internationale v. MicGranery, 111 F. Supp. 435,438 (D.D.C. 1953).

17. See note 11 supra. The court seemed to be aware when it issued the order that difficulties might arise under Swiss law:

"If it develops that plaintiff, after bona fide efforts to obtain access to [the designated] records ... is unable to produce them as ordered, the question of whether further action should be taken by the Court may be considered."

Société Internationale Pour Participations Industrielles et Commerciales, S.A. v. Clarls, 9 F.R.D. 263, 265 (D.D.C. 1949).

18. In any case where the court issues a discovery order, and compliance would be illegal under foreign law, deponent theoretically has a free choice either to comply with the court order or to stay within his own country's law. But practically spealing the dice may be loaded. Where the deponent has discovered that compliance will be unlawiul, his subsequent act of production will be wilfully illegal under foreign law and may subject him to additional punishment. SpEctal. MASTER's REFoRt, op. cit. supro note 11, Findings of Fact No. 28. On the other hand, if he fails to inquire about foreign law and subsequently refuses to comply with the discovery order his good faith will become suspect in United States courts.

The deponent's dilemma can arise from potential liability in a civil suit as well as from threatened punishment under criminal law. In many instances, paying heavy damages to an injured party might be more burdensome to a deponent than paying a light fine to his government.

19. A court clearly has power to order litigants to perform acts outside its territorial jurisdiction, but it can exercise the power only "provided such [acts are] not contrary to the law of the state in which [they are] to be performed." Resistearesi, Corrzucts oz Laws $\$ 94$ (1934). One case has expressly applied the REstaterrext's rule to an act illegal under foreign law. Mexican law prohibited removal of the deponent's records from his place of business, and the court refused to order the deponent to violate that law. It held that if the proponent wished to inspect the records, it had to go to Mexico. SEC v. Minas de Artemisa, 150 F.2d 215 (9th Cir. 1945). The only other decision directly bearing on this question held that plaintiff was not entitled to inspect defendant's records, since inspection would violate the Business Records Protection Act of Ontario. Hirshhorn v. Hirshhorn, 105 N.Y.S.2d $62 S$ (1951) (memorandum decision). There are also some dicta indicating that courts will not force litigants to choose allegiance between court orders and conflicting foreign laws. See Phelps v. MIcDonsld, 99 U.S. 298, 303 (1878) ; Harris v. Pullman, S4 IIl. 20, 28 (1876).

In Societé Internationale, the court distinguished the Mivias de Artcniss case, supra, as dealing only with "accommodation and convenience" and not with "ultimate produc- 
order if compliance would require him to do so. In some instances, of course, foreign law would subject the deponent only to a small fine or other milcl sanction. Then, if the interests at stake in the suit are great and discovery is important to its outcome, a United States court might reasonably require the deponent to produce the documents and suffer the consequences. ${ }^{20}$

But by the time the court delivered its opinion in Sociéte Internationalc, the Swiss government had actually seized the designated documents. ${ }^{\text {21 }}$ In holding that plaintiff still controlled the papers, the court abandoned established interpretation of "control." Previously, courts had examined all the facts to determine whether the deponent was actually able to produce the documents. ${ }^{22} \mathrm{Had}$ this court used that approach, it could not have dismissed the complaint, because Swiss seizure had in fact deprived plaintiff of physical power to comply with the discovery order.

The court departed from precedent partially because it did not want foreign law to "frustrate" domestic rules of procedure. ${ }^{23}$ To be sure, a foreign litigant seeking relief in a United States court must comply with its procedure. ${ }^{\text {a1 }}$ But if, as previously held, Rule 34 instructs the court to decide whether in

tion." Société Internationale v. McGranery, 111 F. Supp. 435, 445 (D.D.C. 1953). But the de Artemisa opinion nevertheless squarely refused to order performance of an illegal act.

Société Internationale analogized performance of an illegal act to self-incrimination. It pointed out that the privilege against self-incrimination does not protect a witness from giving evidence which may lead to his conviction under the laws of another jurisdiction. Société Internationale v. McGranery, supra at 444, See also United States v. Murdock, 284 U.S. 141 (1931). The analogy does not seem apt. Forcing a deponent to perform an illegal act "creates guilt" where none existed before. But forcing a witness to testify can at most illuminate an offense which the witness had previously committed of his own volition.

20. Several countries have laws similar to those invoked in the Sociéte Internationale case, including Canada, Finland and Italy. See communications and reference material on file in Yale Law Library.

The preventive police power is a control "familiar to the European systems of constitutional law." Brief for Plaintiff, August 21, 1951, p. 17, Société Internationale v. McGranery, 111 F. Supp. 435 (D.D.C. 1953). Where a foreign government can exercise such a power to impound documents the practical distinction between illegality and actual seizure may be negligible. The government can seize as soon as it realizes that one of its nationals, under orders from an American court, contemplates an illegal action.

21. See note 16 supra.

22. See notes 4-7 supra and accompanying text.

23. "It seems obvious that foreign law cannot be permitted to obstruct the investigation and discovery of facts in a case, under rules established as conducive to the proper and orderly administration of justice in a court of the United States....

"To adopt any ... course [other than enforcement of the discovery order] would lead only to frustration and nullification of established procedures... and ... impose foreign procedure in trial of suits in United States Courts." Société Internationale v. McGranery, 111 F. Supp. 435, 444 (D.D.C. 1953).

24. See Gooprtch, Conflicts of Laws $\$ 80$ (3d ed. 1949). 
fact the deponent has control, the effect of foreign seizure seems peculiarly relevant. To consider the seizure is not to "apply" foreign law; it is merely to accept a pertinent fact. ${ }^{25}$

While a policy solicitous of domestic litigants' rights can be justified, undue harshness to deserving foreign parties should be avoided. Société Intcrnationale expresses a fear that consideration of the effects of foreign law would enable a foreign litigant to "hide behind" the legislative protection of his government. $^{26}$ And even in the absence of collusion with a foreign government, or bad faith, recognition of foreign law might give such litigants, as well as Americans with documents located abroad, an unfair advantage over domestic adversaries. ${ }^{27}$ But as Rule 34 now reads, it gives no hint that courts should ignore the operation of foreign law in such situations. ${ }^{23}$ Although Société Internationale specifically adopted a finding of no collusion, it nevertheless seems to create a conclusive presumption of collusion or bad faith. ${ }^{29}$ But, by this court's own standards, the deponent can be given the

25. Ironically, the Sociéte Internationale court, in its resolution to prevent foreign law from interfering in American procedure, made Swiss seizure the sole ground for overthrowing the established construction of Rule 34 .

26. "[An opposite result] would permit a foreign government to release only the documents favorable to one party and to retain or destroy the rest ... [and] to stipulate the conditions under which documents required in a court of the United States might be released. . . . It might defeat the purposes of the Trading with the Enemy Act by permitting a foreign national to bring suit in this country to recover property seized under the Act and then scels shelter under the protective cloak of its government when discovery is sought."

Société Internationale v. MIcGranery, 111 F. Supp. 435,444 (D.D.C. 1953).

In parts of its opinion, the court seems strongly influenced by the peculiar nature of the Act under which the suit is brought and elsewhere emphasizes the "privilege" which has been conferred upon plaintiff in permitting it as an alien to bring suit against the United States. The broad grounds for the opinion, however, could pertain to any foreign litigant, whatever the nature of his suit. "The question is when, upon the exercise of this sovereign power [of a foreign country to pass laws], it becomes impossible for a subject to comply with established procedures in this court for securing evidence, should this court permit trial of the case?" Id. at $443-4$.

27. "[A contrary decision] would permit a foreign party to be placed in a favored position by the laws or action of his government." Id. at 444.

28. See note 1 supra.

29. See text at note 13 , and note 26 supra. In light of much of the decision, it is difficult to see just why the court directed the Special Miaster to determine the good faith of plaintifi and its government. Sociéte Internationale Pour Participations Industrielles et Commerciales, S.A. v. Clark, 11 F.R.D. 294, 297 (D.D.C. 1951), or why it adopted his findings. Socièté Internationale v. MIcGranery, 111 F. Supp. 435 (D.D.C. 1953). Onee the court finds good faith, there is no justification for considering the danger of collusion further. Good faith depends on the facts of each case; abstract admonitions will be of little help to future courts.

A good faith finding should involve careful consideration of the deponent's original motivation in locating his records in a country whose law precludes compliance with a 
burden of proving his own good faith and that of the foreign government. So a foreign party or non-resident American could not profit from whatever difficulties arise in bringing forth evidence of activities carried on abroad. ${ }^{\mathrm{a}}$

A discovery order, however, is a feeble tool unless it can be enforced by adequate sanctions. When applied to a deponent whose failure to produce documents results solely from foreign seizure, the most drastic sanctions presently available under Rule 37(b) may be unconstitutional, as well as inequitable, in many instances. ${ }^{32}$ Dismissing the deponent's complaint or rendering default judgment against him has been held constitutional only when his non-compliance was deliberate. ${ }^{33}$ Then the "proven" fact of his

discovery order. Should the court find that the deponent sought thereby to immunize his records from future inspection, it should find bad faith, even though the deponent is presently powerless to produce the records.

For a contention that questions of good faith and collusion should not enter into the court's decision at all, see 66 HARv. L. Rev. 1316, 1317 (1953).

30. Société Internationale v. McGranery, 111 F. Supp. 435, 439, 440 (D.D.C. 1953), SPECIAL MASTER's REPoRT, op. cit. supra note 11, Conclusion No. 1. Since the deponent is likely to have in his possession most of the evidence bearing on his own good faith and that of the foreign government, placing the burden of proof on him seems just.

31. Admittedly, it is difficult to determine the deponent's good faith in acting under foreign law. An American court or Master, holding hearings on the subject, faces prodigious obstacles, including language barriers, unavailability of witnesses, and the "diplomatic" embarrassment which questioning the good faith of a foreign government might occasion. See generally, Nussbaum, The Problem of Proving Foreign Lazu, 50 YALE L.J. 1018 (1941).

32. The Constitution seems to forbid use in this context of any sanction adjudicating the merits of the case. See notes 36, 37 infra and accompanying text. This category includes all the sanctions enumerated in Rule $37(\mathrm{~b})$, except staying proceedings and dismissing a complaint without prejudice. For the Rule's list of sanctions, see note 2 stlpra. Rule 37 authorizes dismissal in general terms only. FED. R. Crv. P. 37(b) (iii). But Rule 41 provides that a court's dismissal shall constitute an adjudication of the merits, unless the court specifies otherwise. FED. R. Crv. P. 41(b).

Granting a stay can never be a final adjudication. In theory, neither can a dismissal without prejudice, since it allows the plaintiff to reinstitute his suit. If, however, the court's dismissal is timed so that the limitations period will run before the plaintiff can bring suit again, the court's action actually amounts to an adjudication of the merits. This is especially true where, as in Société Internationale, plaintiff can purste his claim in no other forum. A court anxious to enforce its discovery order might justify stch a dismissal on the ground that it does not technically adjudicate the merits. But dismissing so that plaintiff cannot sue again seems to do indirectly that which would be unconstitutional if accomplished by frankly dismissing with prejudice. See note 36 infra and accompanying text.

Staying proceedings and dismissing without prejudice may often be unsatisfactory methods of dealing with a recalcitrant deponent. In Société Internationale, for example, any delay in the suit would have hindered the United States, since the Government could not have disposed of property involved in the litigation until a final adjudication was made. See Comment, 62 Y Ale L.J. 1210, 1214 n.28 (1953).

33. Hammond Packing Co. v. Arkansas, 212 U.S. 322 (1909) ; cf. Duell v. Duell, 178 F.2d 683 (D.C. Cir. 1949). But cf. Hovey v. Elliot, 167 U.S. 409 (1897). The Reviser's Note on Rule 37(b) makes it evident that the Rule was intended to derive its 
"wilful suppression of material evidence" gives reason to presume conclusively that his pleadings are untrue. ${ }^{34}$ Hence, they can be striclien. ${ }^{33}$ But where non-compliance is involuntary, a court cannot reasonably infer that the deponent's pleadings are without basis in fact. ${ }^{30}$ And no alternative rationale appears to validate denying the involuntary transgressor his constitutionallysecured right to have his case adjudicated on its merits. ${ }^{37}$ Moreover, when

constitutional validity from the Hammond case. Ammsosr Cosmsmrex's Nore to Fer. R. Crv. P. 37(b). Although they do not expressly discuss constitutionality, later cases interpreting the Rule have held that its sanctions apply only to wilful disobedience. Campbell v. Johnson, 101 F. Supp. 705, 707 (S.D.N.Y. 1951) ; Roth v. Paramount Pietures Distributing Corp., S F.R.D. 31, 32 (W.D. Pa. 1948).

34. Hammond Packing Co. v. Arlansas, supra note 33; see Abrsozy Consuntress Nore to FED. R. Crv. P. 37(b). Both the case and the Note go to considerable effort to distinguish Hovey v. Elliot, stpra note 33, which held the rendering of a default judgment unconstitutional. The distinction employed in both instances was that in Horcy the defendant's answer was stricken as a punishment for contempt, not as the result of a reasonable presumption of untruth. Sie Hammond Packing $C o$. v. Arkansas, supra nute 33, at 349-51. In Hovey, the court entered default judgment because the defendant failed to pay money into court when ordered to do so. See Hovey v. Elliot, susprs note 33, at 411-12. In Hammond, the court entered default judgment beause the defendant failed to produce documents when ordered to do so. Sie Hammond Packing Co. v. Arlansas, supra note 33, at 336-40. Apparently the differences between the two cases are more conceptual than real.

35. Hammond Packing Co. v. Arkansas, stipra note 33.

36. In such a case, the deponent has not "wilfully suppressed" the documents. The mere fact that factors beyond the deponent's control prevent compliance provides no reasonable basis for an inference that his pleadings are worthless. Striling the deponent's pleadings then becomes a denial of due process as outlined in Hovey v. Elliot, stspra note 33. And taking as established the facts which the proponent alleges the unavailable doeuments would prove seems to deny due process under the same rationale See note 2 suspra.

In Société Internationale, the court stated that the constitutionality of its action mas assured by the Hammond case. Société Internationale v. MicGranery, $111 \mathrm{~F}$. Supp. 435, 446, 447 (D.D.C. 1953). But the Hammond court specifically limited its decision to deliberate non-compliance. Hammond Packing Co. v. Arkansas, 212 U.S. 322, 346-7 (1909). Also to justify its decision, the Sociéte Intentationale court interpreted Rule 37 (b) as applying to non-wilful, as well as wilful, disobedience, and found that the deponent had "refused" to obey the discovery order within the meaning of the Rule. Sociéte Internationale v. MicGranery, supra at 446. Even assuming that such a distorted interpretation could be defended, determining the meaning of the Rule does not decide its constitutionality. The opinion also relied heavily on English precedents. Id. at 444-5. It is diffcult to see how British courts could possibly write decisions relevant to the validity of Rule 37 under the United States Constitution.

37. In general, a litigant has a right to a hearing on the merits of his ase. Consolidated Gas Co. v. Mayer, 146 Fed 150, 152 (C.C.S.D.N.Y. 1906); Hovey v. Elliot, 167 U.S. 409,415 (1S97). A few cases have dismissed a party without affording him an adjudication on the merits, but all involve situations distinguishable from that in Sociste Internationale. One decision held that a state can by statute close its courts to an insurance company by forcing the company to arbitrate contract claims. Hardware Dealers Miutual Fire Insurance Co. v. Glidden Co., 284 U.S. 151 (1931). But there the court 
the court has found that the deponent tried in good faith to procure the designated documents, it seems harsh to subject him to sanctions which were designed to penalize only the wilfully disobedient..$^{38}$

A court may nevertheless feel that a proponent whom foreign seizure has robbed of possibly crucial documentary evidence deserves some assistance in formulating his case. If the deponent does not already bear the burden of proving facts contained in the unavailable documents, the court could constitutionally put it upon him. ${ }^{39}$ At least with regard to some issues, the difficulty of producing reliable evidence would put teeth in this sanction. A more frequently effective means of aiding the proponent would be to tax the deponent for costs the proponent reasonably incurs in searching elsewhere

relied on the fact that arbitral process satisfied constitutional requirements by affording the company reasonable notice and opportunity to be heard. Id. at 158.

In Totten v. United States, 92 U.S. 105 (1875), the Court, without mention of any constitutional issue, held that plaintiff could not maintain a claim based upon a confidential contract between himself and the President of the United States. The Court seemed to apply an estoppel rationale; it pointed out that plaintiff must have known that the contract was privileged at the time he entered into it. Id. at 106. Sociét' Internationalc clearly does not present a comparable situation. Plaintiff's suit was specifically authorized by the Trading with the Enemy Act. See note 9 supra. By no stretch of the imagination had he contracted away this right to sue.

Some courts have held that a husband's divorce action will be dismissed if he fails to comply with a court order to pay his wife temporary alimony and attorney fees so that she may defend the suit. E.g., Reed v. Reed, 70 Neb. 779, 98 N.W. 73 (1904). But such cases involve a wilful failure to comply. When non-compliance is involuntary, the most any court has done is to stay proceedings. E.g., Farrar v. Farrar, 45 Cal. App. 584, 188 Pac. 289 (1920). And other courts have expressly held that striking the husband's pleadings when he fails to pay is a denial of due process. Naveja v. Naveja, 110 Misc. 279, 179 N.Y. Supp. 881 (1920), citing Hovey v. Elliot, 167 U.S. 409 (1807). And it seems to be an established doctrine that a defendant husband cannot be forced to suffer default judgment for failure to comply, even when his failure is wilful. E.g., Hutchinson v. Hutchinson, 126 Ore. 519, 270 Pac. 484 (1928).

38. See Advisory Committé's Note to Fed. R. Crv. P. 37(b).

39. Determining what facts documents would prove if they were produced may involve some guesswork. The proponent may seek to inspect them merely on the chance that they might reveal something to support his case. But Rule 34 specifies that he must show good cause for inspection and requires the court to exercise its discretion in ordering production. See note 1 supra. Hence a court must have at least a rough idea of what the documents concern before it can even order discovery. It seems reasonable to allow the court to exercise its discretion again in deciding on exactly what issues the deponent shall bear the burden of proof. In Sociéte Intemationale, for instance, the court would have no trouble in inferring that the deponent's business records would contain information about the corporate ownership.

A court does not deny a litigant due process by placing on him the burden of proving facts peculiarly within his knowledge and hidden from his opponent. Casey v. United States, 276 U.S. 413,418 (1928). A situation where foreign seizure prevents the proponent from inspecting documents of the deponent would seem clearly to fall withir this rule. The deponent is in a "peculiarly" good position to know the facts which the documents contain, and the seizure "hides" the contents from the proponent. 
for similar evidence. ${ }^{40}$ Not only might such an assessment help a proponent when documents are unavailable, but also fear of the levy should arouse a deponent into making every possible effort to produce the documents in the first place. Although these sanctions would not be mandatory or effective in all situations, courts faced with involuntary non-compliance would have them available to assure both parties as fair a trial as the circumstances permit.

40. Under FED. R. Crv. P. 54(d), costs are generally allowed "as [a matter] of course to the prevailing party." But under "special circumstances," a court can, in its diseretion, apportion costs differently. Globe Indemnity Co. v. Puget Sound Co., 154 F.2d 249, 251 (1946) ; accord, United Building \& Loan Ass'n v. Garnett, 64 F. Supp. 460 (W.D. Arls 1946). Specifically, district courts have the power to award costs to one party and tax them to his opponent. Swalley v. Addressograph-MIultigraph Corp., 16S F.2d 5S5 (7th Cir. 1948), cert. denied, 335 U.S. 911 (1949).

In some cases, of course, the sanction might be ineffective because no evidence other than the missing documents can be found. But that situation would seem to be the exception rather than the rule. Certainly in Sociate Intersationale it seems that the Government might well have procured evidence of enemy ownership by malsing investigations in Germany. In fact the deponent alleged that the Government already had such evidence in its possession. See Société Internationale v. MrGranery, 111 F. Supp. 435, 442 (D.D.C. 1953).

41. Of course, since Rule 37 (b) authorizes any order which is "just," see note 2 supro, a court could also meet deliberate non-compliance by shifting the burden of proof or apportioning costs, if it seemed equitable to do so. 